\title{
An Analysis of the Throughput Rate of Doctoral Students in LIS Schools in South Africa, 2005-2015
}

\author{
Jan Maluleka \\ https://orcid.org/0000-0002-3760-8162 \\ University of South Africa \\ maluljr@unisa.ac.za
}

\author{
Mpho Ngoepe \\ https://orcid.org/0000-0002-6241-161X \\ University of South Africa \\ Ngoepms@unisa.ac.za
}

\section{Abstract}

South African universities produce fewer graduates than the number specified in the National Development Plan (NDP). According to the NDP, South Africa needs more than 5000 doctoral graduates annually, against the 1420 produced in 2010 and 2258 in 2014. The 2030 target is to produce more than 100 doctorates per million people per year, as the current figures are below international standards. This study employed informetric research techniques as the main method, triangulated through questionnaires administered to doctoral supervisors to examine the throughput rates of doctoral students in the field of library and information science (LIS) at public universities in South Africa between 2005 and 2015. Data were extracted from institutional repositories of universities offering LIS in South Africa, and after the relevant information (i.e. gender, race, institution, and nationality of both students and supervisors) had been obtained, the data were saved and analysed in Microsoft Excel spreadsheets. Key results suggest a low throughput rate of doctoral students in LIS schools. The findings further suggest that social factors such as the gender, race and nationality of doctoral students in relation to those of their supervisors have a direct impact on the completion of doctoral projects in LIS schools.

Keywords: doctoral students; library and information science; National Development Plan; South Africa

\section{Introduction and Background to the Study}

There has been a growing interest globally among researchers, governments and various stakeholders in the production of graduates with postgraduate qualifications, especially at doctoral level. This may have been fuelled by the demand on the part of current economies for a highly knowledgeable workforce. According to MacGregor (2013), Africa considerably needs more holders of postgraduate qualifications to replenish the

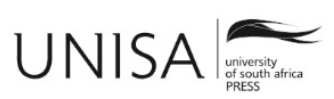


current ageing group of professionals, to further staff the rapidly expanding higher education sector, to boost research, and to generate the high-level skills the countries' growing economies need. In South Africa, to increase the throughput, the government subsidises each doctoral student, irrespective of gender, nationality or race, with an amount of R60 000 per annum until the study is completed (Department of Higher Education and Training 2016). Despite this, institutions of higher learning are failing to meet the economic needs of the country. For example, South African universities produce fewer graduates than the required number as set out in the country's National Development Plan (NDP). According to the NDP (National Planning Commission 2013), South Africa needs more than 5000 doctoral graduates per year, against the 1420 produced in 2010 and 2258 in 2014. The 2030 target is to produce more than 100 doctorates per million people per year, as the current figures are below international standards.

These and many other factors initiated a surge in interest in studies investigating postgraduate research throughputs similar to the current study. It is not clear what factors contribute to less production of doctoral graduates in South Africa, whether it is the students who do not pull up their socks, or the resources or academics that are holding students back from completing their studies, as analogised in the scripture from the book of Exodus 9:1 in the holy Bible. It would seem that the situation pertaining to doctoral students enrolled for library and information science (LIS) in South Africa is particularly dismal. For example, Raju (2015) contends that LIS schools in South Africa experience difficulties in attracting quality students, and academic staff are unable to respond to the demands of the NDP and the digital era. However, the situation is not unique to South Africa and LIS.

Prompted by global concern relating to problems associated with postgraduate training by academic institutions, Botha (2016) examined postgraduate research trends at the University of Ghana, and identified factors contributing to a decrease in student throughput over time which included financial difficulties, personal problems and the difficulties students experienced in being granted study leave by their employers. Similarly, Sonn (2016) identified the formulation of the problem statement, the complexity of proposal writing and the lack of professional writing skills as some of the reasons contributing to students' dropout. Students require support, which is provided mainly by supervisors. Van Rensburg, Mayers and Roets (2016) explain that "the role of the supervisor in providing a supportive, constructive and engaged supervision process is important to ensure that the future generation of students have the right educational and skills mix to fulfil the needs of the profession”. Vivian and Fourie (2016) conducted a study in which they investigated the nature of support to students by supervisors at a selected number of universities in South Africa. The results of their study suggest that most universities in South Africa have formalised support for postgraduate students. 
With regard to the supervision of students, Van Rensburg, Mayers and Roets (2016) considered various factors in relation to the supervision of postgraduate students. Their study emphasised that supervision is a learning and developmental process involving the supervisor and the student. Both the supervisor and the student should work to ensure the success of the relationship by demonstrating tolerance, appreciation, respect, honesty and trustworthiness. Hodza (2007) also investigated factors influencing the relationship between students and supervisors at master's and doctoral level, with the findings suggesting that the relationship between a student and his/her supervisor is influenced by various social factors such as gender, culture, and nationality. The current study seeks to investigate the throughput rate of LIS doctoral students in South African universities from 2005 to 2015, with a view to assessing the contribution of LIS schools to the targets set by the NDP. The current study determines the top producers of LIS doctoral graduates, as well as the contributing social factors.

\section{Purpose of the Study}

The purpose of this study was to apply informetric research techniques supplemented by a questionnaire to ascertain the throughput rates of LIS doctoral students between 2005 and 2015, and further to consider the social factors that might have influenced such trends. The specific objectives were to determine

- the annual throughput of LIS doctoral graduates between 2005 and 2015,

- the top producing supervisors per school per year between 2005 and 2015,

- the nationality, race and gender of the top performing supervisors,

- the nationality, gender and race of the students who graduated in the ten-year period, and

- reasons for the observed trends.

\section{Contextual Setting}

In South Africa, LIS schools are schools or departments that offer more general or theoretical education in LIS, and also offer undergraduate and postgraduate degree qualifications which take three to four years for undergraduates, and between one and three years for honours, master's and doctoral qualifications (Ocholla and Bothma 2007; Raju 2005). According to Ocholla and Bothma (2007), the LIS sector in South Africa consisted of only 12 LIS schools in 2006, down from the 18 that existed in 2000. In 2011, only 10 schools were offering LIS-specific subjects (Maluleka and Onyancha 2016; Raju 2015). From the results of the current study it seems there are nine LIS schools remaining because the Walter Sisulu University has no evidence of LIS offerings even from their website. For that reason the nine LIS schools remaining in South Africa are located at the following institutions: the University of South Africa 
(UNISA), the University of Pretoria (UP), the University of KwaZulu-Natal (UKZN), the University of Zululand (UNIZULU), the University of Fort Hare (UFH), the University of Cape Town (UCT), the University of the Western Cape (UWC), Durban University of Technology (DUT), and the University of Limpopo (UL). Despite offering LIS modules, the University of Johannesburg was excluded from the study, as the focus of the curriculum is no longer on LIS, but rather on management and business intelligence.

UNISA offers LIS qualifications from a diploma, graduate and postgraduate level. UP offers qualifications from undergraduate to postgraduate levels in the areas of information science, multimedia and publishing studies. Some of the areas they specialise in include knowledge management, virtual reality, and electronic publishing. UKZN offers study programmes in information literacy at undergraduate level and their LIS offerings are mainly at postgraduate level. UNIZULU offers information studies programmes at undergraduate level as well as postgraduate level up to $\mathrm{PhD}$ level. UFH offers training at both undergraduate and postgraduate levels in the subject areas such as cataloguing, classification, documentation, information and communication technologies, and library organisation and management. UCT provides postgraduate courses such as digital curation, research librarianship, LIS leadership and management, knowledge management, resource description and communication. UWC offers qualifications from undergraduate to postgraduate level up to PhD level. The DUT offers a national diploma, bachelor's degree, master's degree as well as a PhD in LIS. Finally, the UL offers LIS programmes from undergraduate and postgraduate up to $\mathrm{PhD}$ level. Therefore, the current study was based on the nine public universities in South Africa listed above. Even though it is based on a small discipline, it is hoped that the study will influence the funding formula for the marginalised and neglected disciplines in South Africa.

\section{Problem Statement}

There is consensus among scholars with regard to the slow growth in the production of master's and doctoral graduates across institutions of higher learning in South Africa. The majority of these studies based their arguments on the general throughput rates obtained from statistical reports from these institutions. A study by Mouton (2007) interrogated some of the current views and myths about postgraduate studies, especially at master's and doctoral level in South Africa. The study highlighted trends in postgraduate completion rates and compared these with global trends. Hodza (2007) established that the supervisory relationship in postgraduate education is influenced by various social factors such as gender, culture and nationality. Academic departments in South African universities accept students from all over the world and employ experienced staff members from various countries to strengthen their workforce. It is not clear from the available statistics how South Africa is really faring. 


\section{Scope and Research Methodology}

This study employed informetric research techniques to examine LIS doctoral outputs in South African LIS schools between 2005 and 2015. Data were extracted from the Current and Completed Research Projects Database of the Nexus Database System of the National Research Foundation (NRF), the Current and Completed Research database of the Southern African Bibliographic and Information Network (SABINET), as well as the institutional repositories of selected LIS Schools.

An Excel spreadsheet reflecting completed doctoral studies, doctoral supervisors, students and their nationality, gender and race between 2005 and 2015 was created for further analysis. The investigators acknowledge that not all the records were captured for analysis because some institutional repositories were not updated regularly. In cases were the data were not clear on a student's gender, nationality and race, the investigators consulted websites such as ResearchGate, LinkedIn and Google Scholar Citations, actual theses and dissertations, and asked colleagues for information. Duplicate entries were identified and eliminated.

An anonymous questionnaire was sent to selected supervisors attached to the nine LIS schools in South Africa to triangulate the data. A total of 42 questionnaires were sent to professors, senior lecturers and lecturers with a $\mathrm{PhD}$ qualification, because the investigators were of the view that in order to supervise a doctoral study, the supervisor should have completed that qualification himself/herself. Stellar survey online software was used and personal emails were sent to each scholar in an effort to increase the response rate. The survey was left open for up to four weeks. In total, 42 questionnaires were sent out and 22 respondents completed the survey. The respondents were informed as to who was conducting the research, why they were being invited to participate, that participation was voluntary and that they were free to withdraw at any time, and that anonymity and confidentiality would be maintained at all times.

\section{Limitations to the Study}

This study relied on the theses obtained from the NRF and SABINET databases as well as institutional repositories from the nine LIS schools. These sources of data had their own limitations. Some of the theses were not listed in the databases and the majority of the repositories were not up to date. Secondly, the investigators relied on the LIS schools websites for contact details of LIS supervisors for participation in the survey questionnaire. Some of these websites were not updated regularly, and as a result new members who recently joined those departments could not be reached. Therefore, these issues need to be taken into consideration when interpreting the results. 


\section{Ethical Considerations}

It is important to always consider research ethics when doing research, because research is a public trust that must be conducted in an ethical, trustworthy and socially responsible way if the results are to be valuable (University of Minnesota, 2003, 6). For this study, an ethical clearance was obtained from the University of South Africa. This is because the protection of human participants in any research study is very important. In the process of conducting this study, the researcher made sure the participants knew and understood what the research involved. Respondents were informed that participation in the study was voluntary and no one was exposed to harm.

\section{Results and Discussions}

The present section discusses the results of the study obtained from both the informetric data and the survey questionnaire. Of the 42 questionnaires sent out, only 22 were returned. This means that the study yielded a response rate of 52 per cent. Furthermore, the investigators downloaded and analysed 111 completed doctoral studies from the 9 LIS schools between 2005 and 2015. The data are presented under the following subheadings:

- Profile of the respondents

- $\mathrm{PhD}$ output per institution per year

- Top producing supervisors

- Reasons why South African supervisors may not be producing more students

- Student output by nationality

- Reasons why South African students are not doing well when compared with students from other countries

- Student output by race

- Reasons why other races had higher numbers in other institutions

- Student output by gender

\section{Profile of Respondents}

Of the 22 (52\%) respondents, 9 (41\%) were male and 13 (59\%) were female (see Figure 1). With regard to age, 2 (9\%) of the respondents were between 36 and 40 years old, 4 (18\%) were between 41 and 45, 7 (31\%) were between 46 and 50, 4 (18\%) were between 51 and 60, and 5 (23\%) were over the age of 60 (see Figure 2). 


\section{GENDER}

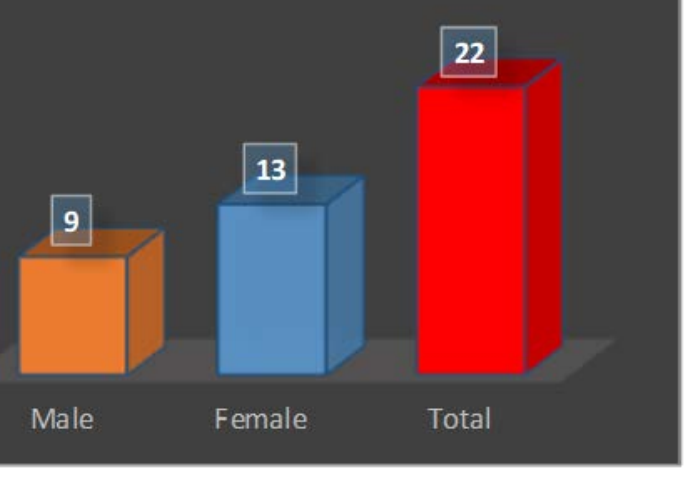

Figure 1: Gender $(\mathrm{N}=22)$

\section{AGE AND AGE PERCENTAGE}

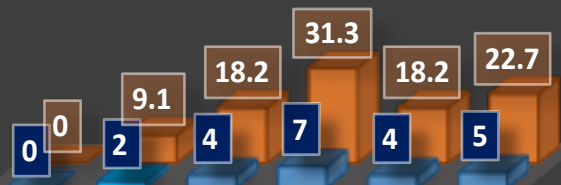

25-35 36-40 41-45 46-50 51-60 over

Figure 2: Age $(\mathrm{N}=22)$

Figure 3 presents the nationality of the respondents, while Figure 4 presents their academic rank. As indicated in Figure 3, 17 (77\%) of the respondents were South African, while 5 (23\%) were non-South African. In terms of academic rank, 2 (9\%) were lecturers, 10 (46\%) were senior lecturers, 7 (32\%) were associate professors, and 3 (14\%) were full professors. 


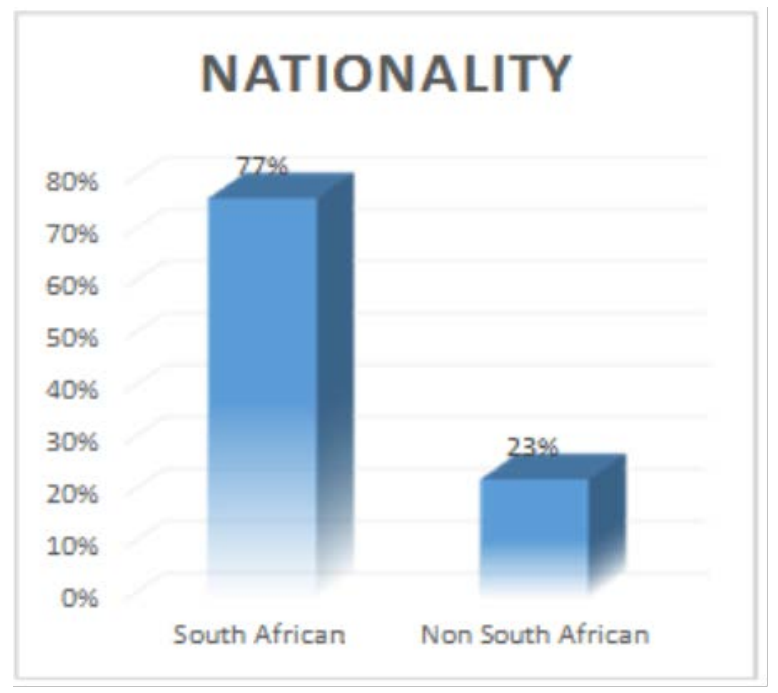

Figure 3: Nationality

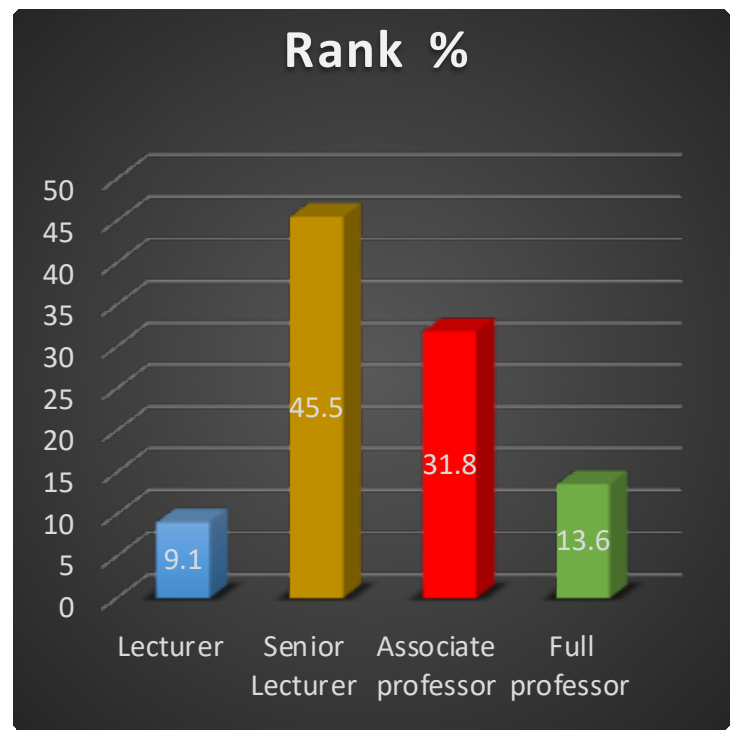

Figure 4: Academic rank

\section{PhD Output per Institution per Year}

Table 1 shows the LIS doctoral output in the ten-year period between 2005 and 2015 as captured in the institutional repositories, the Current and Completed Research Projects Database of the Nexus Database System of the NRF as well as SABINET's Current and Completed Research database. In the ten-year period, the DUT, FH and UL produced 
one $\mathrm{PhD}$ graduate each. UCT and UWC each recorded five completed doctoral studies. UNIZULU had 16, while UP recorded 23. UKZN and UNISA produced the largest number, namely 29 and 30 respectively.

Table 1: PhD output per institution per year $(\mathrm{N}=111)$

\begin{tabular}{|c|c|c|c|c|c|c|c|c|c|c|c|c|}
\hline & $\begin{array}{l}\text { N } \\
\text { \& } \\
\text { u }\end{array}$ & 尺̊ & 尺̊ & $\underset{\infty}{\mathscr{8}}$ & $\begin{array}{l}\text { 용 } \\
\text { ठ }\end{array}$ & 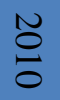 & $\stackrel{\sim}{\ominus}$ & $\stackrel{\text { O }}{\stackrel{N}{N}}$ & $\stackrel{\text { }}{\stackrel{\omega}{\omega}}$ & $\underset{\oplus}{\stackrel{\sim}{\oplus}}$ & $\begin{array}{l}\text { 今 } \\
\text { ज़ }\end{array}$ & \\
\hline $\begin{array}{l}\text { Durban University of } \\
\text { Technology }\end{array}$ & 0 & 0 & 0 & 0 & 0 & 0 & 0 & 0 & 0 & 0 & 1 & 1 \\
\hline Fort Hare & 0 & 0 & 0 & 0 & 0 & 0 & 0 & 1 & 0 & 0 & 0 & 1 \\
\hline $\begin{array}{l}\text { University of Cape } \\
\text { Town }\end{array}$ & 2 & 2 & 1 & 0 & 0 & 0 & 0 & 0 & 0 & 0 & 0 & 5 \\
\hline $\begin{array}{l}\text { University of } \\
\text { KwaZulu-Natal }\end{array}$ & 1 & 0 & 1 & 2 & 0 & 3 & 1 & 3 & 1 & 8 & 9 & 29 \\
\hline $\begin{array}{l}\text { University of } \\
\text { Limpopo }\end{array}$ & 0 & 0 & 0 & 0 & 1 & 0 & 0 & 0 & 0 & 0 & 0 & 1 \\
\hline $\begin{array}{l}\text { University of } \\
\text { Pretoria }\end{array}$ & 3 & 2 & 3 & 6 & 3 & 4 & 0 & 1 & 0 & 1 & 0 & 23 \\
\hline $\begin{array}{l}\text { University of South } \\
\text { Africa }\end{array}$ & 1 & 3 & 3 & 1 & 0 & 3 & 1 & 4 & 2 & 6 & 6 & 30 \\
\hline $\begin{array}{l}\text { University of the } \\
\text { Western Cape }\end{array}$ & 1 & 1 & 1 & 0 & 0 & 0 & 0 & 1 & 0 & 0 & 1 & 5 \\
\hline $\begin{array}{l}\text { University of } \\
\text { Zululand }\end{array}$ & 1 & 0 & 4 & 0 & 0 & 0 & 1 & 1 & 6 & 1 & 2 & 16 \\
\hline Total & 9 & 8 & 13 & 9 & 4 & 10 & 3 & 11 & 9 & 16 & 19 & 111 \\
\hline
\end{tabular}

\section{Top Producing Supervisors}

Table 2 presents supervisors who supervised the largest number of doctoral studies to completion between 2005 and 2015. Only supervisors who supervised three or more doctorates are reflected in the table. Drs Stillwell, Ocholla, Ngulube and Mutula each produced over ten doctorates over the ten-year period. The top five positions were occupied by three non-South Africans. The results indicate that only one female black South African and not a single male black South African obtained a PhD in the ten-year period. 
Table 2: Top producing supervisors $(\mathrm{N}=17)$

\begin{tabular}{|l|l|c|l|l|}
\hline Name & Institution & Number of PhDs & Nationality* & Gender \\
\hline Stillwell & UKZN & 15 & South African & Female \\
\hline Ocholla & UNIZULU & 15 & Non-South African & Male \\
\hline Ngulube & UNISA & 14 & Non-South African & Male \\
\hline Mutula & UKZN & 11 & Non-South African & Male \\
\hline Hoskins & UKZN & 9 & South African & Female \\
\hline Van der Walt & UNISA & 7 & South African & Male \\
\hline Le Roux & UNIZULU & 6 & South African & Male \\
\hline Underwood & UCT & 5 & South African & Male \\
\hline Dick & UP & 4 & South African & Male \\
\hline Majanja & UNISA & 4 & Non-South African & Female \\
\hline Mostert & UNIZULU & 4 & South African & Female \\
\hline Snyman & UP & 4 & South African & Male \\
\hline Bothma & UP & 4 & South African & Male \\
\hline Gericke & UNISA & 3 & South African & Female \\
\hline Machet & UNISA & 3 & South African & Female \\
\hline Dube & UNISA & 3 & South African & Female \\
\hline Fredericks & UWC & 3 & South African & Male \\
\hline
\end{tabular}

*For non-South Africans we did not consider naturalisation.

\section{Reasons why South African Supervisors may not be Producing more Students}

The following were listed as the possible reasons why South African supervisors were not producing more doctoral graduates:

- the levels of training for supervisors need to be improved;

- emerging supervisors must be offered induction and support in both the supervision and examination of $\mathrm{PhD}$ theses;

- too few supervisors are available, and thus too many students are assigned to each supervisor;

- there is complete absence of guidance from senior scholars in the country;

- the only resource available to supervisors was what they had learnt from their supervisors when they themselves were doing their $\mathrm{PhD}$; and

- some students are underprepared for higher levels of study. 


\section{Student Output by Nationality}

Table 3 shows that of the total doctoral studies analysed, 54 per cent were awarded to non-South Africans, while 46 per cent were awarded to South Africans. Three of the main producers of doctoral students produced more non-South African than South African holders of doctoral qualifications: UKZN produced 67 per cent non-South African and 31 per cent South African doctorate holders, UNISA produced 60 per cent non-South African and 40 per cent South African doctorate holders, while the UNIZULU produced 75 per cent non-South African and only 25 per cent South African doctorate holders. UP was the main producer of South African doctorates, with 83 per cent South African and only 17 per cent non-South African doctorates.

Table 3: Output by nationality $(\mathrm{N}=111)$

\begin{tabular}{|l|l|l|}
\hline \multicolumn{2}{|l|}{ South Africans } & Non-South Africans \\
\hline Durban University of Technology & $1(100 \%)$ & 0 \\
\hline Fort Hare & 0 & $1(100 \%)$ \\
\hline University of Cape Town & $2(40 \%)$ & $3(60 \%)$ \\
\hline University of KwaZulu-Natal & $9(31.03 \%)$ & $20(68.96 \%)$ \\
\hline University of Limpopo & $1(100 \%)$ & 0 \\
\hline University of Pretoria & $19(82.60 \%)$ & $4(17.39 \%)$ \\
\hline University of South Africa & $12(40 \%)$ & $18(60 \%)$ \\
\hline University of the Western Cape & $3(60 \%)$ & $2(40 \%)$ \\
\hline University of Zululand & $4(25 \%)$ & $12(75 \%)$ \\
\hline Total & $51(45.94 \%)$ & $60(54.05 \%)$ \\
\hline
\end{tabular}

\section{Reasons why South African Students are not Doing Well when Compared with Students from Other Countries}

The following were cited by the respondents as the possible reasons why South African students are not doing well as compared with students from other countries studying in South Africa:

I do not experience the SA students as driven and motivated as the foreign students.

With a first degree, South Africans can secure jobs. Other nationalities have to go two or more years up. Alternatively, must bring in to SA critical skills.

Teaching overload, topics chosen by students.

Most of my postgraduate research students are non-South Africans.

I have supported some students in RSA universities, but these were not South Africans. 
Money plays a big factor in further studies.

Few South African students enrolled at my institution.

The commitment especially considering that mostly students from other countries are able to focus on their studies full time as compared to their counterparts in South Africa.

South Africans, especially black students, do not support one another, when one gets to the top they forget those who are following which is not the same with other nations.

When given a chance, South African students do not take advantage of the opportunities, they sometimes misuse the funds they get through bursaries and end up not completing their qualification.

\section{Student Output by Race}

Table 4 shows LIS doctoral output by race between 2005 and 2015. Overall, 67 per cent of the doctorates were awarded to black candidates, followed by 29 per cent awarded to white candidates, with just under 2 per cent awarded to Indian and mixed-race candidates. With the exception of UP, the main producers of doctorates in the country (UNIZULU, UKZN and UNISA) awarded more doctorates to black candidates than to candidates of other races. UP awarded more doctorates to white students than to students of other races, with a little under 70 per cent of completed doctorates being awarded to white candidates and 26 per cent to black candidates.

Table 4: Output by race $(\mathrm{N}=111)$

\begin{tabular}{|c|c|c|c|c|}
\hline & $\begin{array}{l}\text { Black } \\
\text { candidates }\end{array}$ & $\begin{array}{l}\text { Mixed-race } \\
\text { candidates }\end{array}$ & $\begin{array}{l}\text { White } \\
\text { candidates }\end{array}$ & $\begin{array}{l}\text { Indian } \\
\text { candidates }\end{array}$ \\
\hline $\begin{array}{l}\text { Durban University of } \\
\text { Technology }\end{array}$ & $1(100 \%)$ & 0 & 0 & 0 \\
\hline Fort Hare & $1(100 \%)$ & 0 & 0 & 0 \\
\hline $\begin{array}{l}\text { University of Cape } \\
\text { Town }\end{array}$ & $3(60 \%)$ & 0 & $2(40 \%)$ & 0 \\
\hline $\begin{array}{l}\text { University of } \\
\text { KwaZulu-Natal }\end{array}$ & 26 (89.65\%) & 0 & 2 (6.89\%) & $1(3.44 \%)$ \\
\hline University of Limpopo & $1(100 \%)$ & 0 & 0 & 0 \\
\hline University of Pretoria & $6(26.08 \%)$ & 0 & $16(69.56 \%)$ & $1(4.34 \%)$ \\
\hline $\begin{array}{l}\text { University of South } \\
\text { Africa }\end{array}$ & $20(66.66 \%)$ & 0 & $10(33.33 \%)$ & 0 \\
\hline $\begin{array}{l}\text { University of the } \\
\text { Western Cape }\end{array}$ & $2(40 \%)$ & $2(40 \%)$ & $1(10 \%)$ & 0 \\
\hline University of Zululand & 15 (93.75\%) & 0 & $1(7.25 \%)$ & 0 \\
\hline Total & 75 (67.56\%) & $2(1.8 \%)$ & 32 (28.82\%) & $2(1.8 \%)$ \\
\hline
\end{tabular}




\section{Reasons for Higher Numbers of Other Races in Other Institutions}

When supervisors were asked about possible reasons for the higher numbers of doctorate holders of other races produced by their institutions, the following answers were given:

Mainly because I was the coordinator of a course in Development Communication of which the students were mainly African.

They are the ones available for us. Besides, black students see further studies as a source of securing better opportunities.

Availability of funding, lack of interest in PhDs from industry.

Demographics at my University.

My university has a higher number of black students. It is a predominantly black university.

Population dynamics: the number in each category in proportion to the population.

Black students tend to incline to black lecturers/supervisors. In some instances, I think it is because our department has mostly black students and very few white students.

Students were from African countries - not South Africa.

Previously disadvantaged races are only now completing first and second degrees. It will take some time for them to get to $\mathrm{PhD}$ level.

The fact that most of my doctoral students came from other African countries.

The department attracts more non-South African students at the doctoral level. Most students are not from South Africa.

\section{Student Throughput by Gender}

Table 5 presents the student throughput by gender at the various institutions. There seems to be a balance in numbers when it comes to LIS doctorates awarded by gender in South Africa. Overall, in the 10-year period, 51 per cent of doctorates were completed by male candidates, while a little under 49 per cent were completed by female candidates. Of the doctorates awarded by UNIZULU, 62 per cent were awarded to male candidates and 37 per cent to female candidates, and of the doctorates awarded by UP, 52 per cent were awarded to female and 47 per cent to male candidates. 
Table 5: Throughput by gender $(\mathrm{N}=111)$

\begin{tabular}{|l|l|l|}
\hline Durban University of Technology & Male & Female \\
\hline Fort Hare & $1(100 \%)$ & $1(100 \%)$ \\
\hline University of Cape Town & $3(60 \%)$ & $2(40 \%)$ \\
\hline University of KwaZulu-Natal & $15(51.72 \%)$ & $14(48.27 \%)$ \\
\hline University of Limpopo & $1(100 \%)$ & 0 \\
\hline University of Pretoria & $11(47.82 \%)$ & $12(52.17 \%)$ \\
\hline University of South Africa & $15(50 \%)$ & $15(50 \%)$ \\
\hline University of the Western Cape & $1(20 \%)$ & $4(80 \%)$ \\
\hline University of Zululand & $10(62.5 \%)$ & $6(37.5 \%)$ \\
\hline Total & $57(51.35 \%)$ & $54(48.64 \%)$ \\
\hline
\end{tabular}

\section{Conclusion and Recommendations}

It is clear from the results that the NDP target of more than 100 doctorates per million people per year in South Africa may not materialise because of disciplines such as LIS, which contribute very little to the national targets. Of the nine LIS schools currently offering training up to PhD level, only four (UKZN, UNISA, UNIZULU and UP) are contributing the bulk of the LIS doctorates in South Africa. The other LIS schools have merged with other departments because of staffing problems and low student numbers and seem to be in danger of being closed down because of low throughput.

The completion of a doctoral qualification requires hard work and dedication. However, there are also social factors that play a key role in the whole process. The relationship between the student and the supervisor can either help or hinder the entire project. Hodza (2007) argues that the relationship between a student and the supervisor is influenced by social factors such as gender, culture, and nationality.

Results of the current study suggest that nationality influences the relationship between the supervisor and the students to some degree. Of the total number of doctorates analysed, 54 per cent were awarded to non-South African students. This may have been influenced by the fact that most of the top positions in the list of top producing supervisors were occupied by non-South Africans. There were no male black South Africans and only one female black South African on the list of top ranked producers. This was further highlighted by the numbers at UP, most of whose workforce consisted of South African supervisors, and which ultimately produced 83 per cent of the South African doctoral holders. The statistics reveal that non-South African supervisors produced more non-South African students than they produced South African students at doctoral level. 
Factors such as time, finances, motivation, lower numbers, lack of commitment, work pressure and lack of seriousness are some of the reasons identified by some supervisors as to why South African students are not performing as well as non-South African students. Some supervisors commented that non-South African students come to South Africa to do their PhDs on borrowed time, which motivates them to complete their studies quickly and return to their workplaces in their countries.

Race also seems to be an important factor when it comes to the relationship between supervisors and students. The statistical results suggest that most of the black students were supervised by black supervisors, and the majority of the white students were supervised by white supervisors. UP was the main producer of South African doctorate holders, the majority of whom (70\%) were white students. This was also influenced by the staff assigned to doctoral supervision: the majority of the supervisors at UP are white. The other three main producers of holders of doctoral qualifications (UNISA, UKZN and UNIZULU) produced the largest number of black doctorate holders. This correlates with the number of black supervisors employed. Some of the reasons cited by the supervisors as to why race played a role in supervision included university demographics, black students tend to incline to black lecturers or supervisors, and the fact that previously disadvantaged races are only now completing first and second degrees, and as a result it will take some time for them to get to $\mathrm{PhD}$ level. Gender seems to have little impact when it comes to the relationship between supervisors and students, because the numbers were not that far apart.

It is recommended that much larger studies at institutional and national level be conducted which will give policymakers an idea of how South Africa is faring in terms of doctoral outputs. Furthermore, disciplines such as LIS, which are contributing very little to the national targets, must be investigated so that the difficulties that they are facing can be identified and resolved for the benefit of the country. It is also recommended that universities prioritise South African students at doctoral level, especially where issues of capacity are involved. Departments must not turn down students for reasons of capacity while spaces are being filled by students from other countries. While more foreign $\mathrm{PhD}$ students produced are important and contribute to the university rankings, it is recommended that there should be greater focus on the South African students for the benefit of the country's economy. This can be done by offering higher incentives to supervisors who produce South African doctoral students.

The South African government, as the biggest employer, should recognise higher qualifications so as to encourage $\mathrm{PhD}$ enrolments. The private sector should follow suit in order to usher South Africa in the research economy. It is therefore recommended that South Africans who obtain higher qualifications be recognised by being employed in senior positions to help drive the country's economy. Failure to transform the situation would lead to more woes such as those experienced with regard to the 
\#FeesMustFall ${ }^{1}$ student movement, as the majority of government-funded foreign doctoral students leave the country after qualifying. As a result, the South African economy does not benefit much from the doctoral graduates produced by institutions of higher learning in this country.

\section{References}

Botha, R. J. 2016. "Postgraduate Throughput Trends: A Case Study at the University of Ghana.” Journal of Social Sciences 49 (1-2): 58-66.

https://doi.org/10.1080/09718923.2016.11893597.

Department of Higher Education and Training. 2016. Annual Monitoring Report on the Projected 2014 Targets of the Ministerial Statement on Students Enrolment Planning, 2014/15 - 2019/20. Accessed 3 September 2017.

http://www.dhet.gov.za/Reports\%20Doc\%20Library/Annual\%20monitoring\%20report\%2 0Projected\%202014\%20targets\%20on\%20student\%20enrolment\%20planning\%20\%20Ministerial\%20statement.pdf.

Hodza, F. 2007. "Managing the Student-Supervisor Relationship for Successful Postgraduate Supervision: A Sociological Perspective.” South African Journal of Higher Education 21 (8): 1155-65. https://hdl.handle.net/10520/EJC37409.

MacGregor, K. 2013. Where to from Here for the African PhD? Accessed 16 June 2017. http://www.universityworldnews.com/article.php?story=20131102155412705.

Maluleka, J. R., and O. B. Onyancha. 2016. "Research Collaboration among Library and Information Science Schools in South Africa (1991-2012): An Informetrics Study.” Mousaion 34 (3): 36-59. https://doi.org/10.25159/0027-2639/1082.

Mouton, J. 2007. "Post-Graduate Studies in South Africa: Myths, Misconceptions and Challenges.” South African Journal of Higher Education 21 (8): 1078-90. https://hdl.handle.net/10520/EJC37415.

National Planning Commission. 2013. National Development Plan: Vision for 2030. Accessed 6 December 2016. http://www.gov.za/issues/national-development-plan-2030.

Ocholla, D. N. and T. Bothma. 2007. "Library and Information Education and Training in South Africa.” In Libraries for the Future: Progress and Development of South African Libraries, edited by T. J. D. Bothma, P. Underwood and P. Ngulube, 149-168. Pretoria: LIASA.

http://www.dissanet.com/ifla/pdf/LIASA\%2011\%20Ocholla\%20\&\%20Bothma.pdf.

1 \#FeesMustFall is a student-led protest movement that began in mid-October 2015 in response to an increase in fees at South African universities. 
Raju, R. 2005. "LIS Education and Training in South Africa: A Historical Review.” South African Journal of Libraries and Information Science 71 (1): 74-84. http://dx.doi.org/10.7553/71-1-656.

Raju, J. 2015. "LIS Education in South Africa: An Overview of the Current Position.” State of Libraries in South Africa March 2016: 42-44. http://www.liasa-new.org.za/wpcontent/uploads/2015/09/State-of-SA-libraries-2015.pdf.

Sonn, R. 2016. "The Challenge for a Historically Disadvantaged South African University to Produce more Postgraduate Students.” South African Journal of Higher Education 30 (2): 226-241. http://dx.doi.org/10.20853/30-2-601.

University of Minnesota. 2003. A Guide to Research Ethics. Accessed 6 June 2015. http://www.ahc.umn.edu/img/assets/26104/Research_Ethics.pdf.

Van Rensburg, G. H., P. Mayers, and L. Roets. 2016. "Supervision of Post-Graduate Students in Higher Education.” Trends in Nursing 3(1). http://dx.doi.org/10.14804/3-1-55.

Vivian, B., and R. Fourie. 2016. "Non-Curricular Postgraduate Writing Interventions at South African Universities.” Journal for Language Teaching 50 (1): 145-65. http://dx.doi.org/10.4314/jlt.v50i1.7. 